\title{
AUTHOR GALLERY
}

Galeria autorska to cykl, w którym publikujemy dzieła wybitnych twórców obrazu, fotografów, rysowników, grafików. W tym numerze $\mathrm{w}$ naszej galerii

\section{AGNIESZKA ŁUKASZEWSKA}

Urodzona 1974 w Krakowie. Studia na Wydziale Grafiki ASP w Krakowie, dyplom (z wyróżnieniem) w Pracowni Rysunku prof. Włodzimierza Kotkowskiego (2000). W roku 2003 otrzymała Stypendium Twórcze Miasta Krakowa. W 2008 uzyskała doktorat na Wydziale Grafiki ASP w Krakowie. Pracuje na stanowisku adiunkta w Pracowni Rysunku na Wydziale Grafiki ASP w Krakowie. Uprawia rysunek, grafikę i rzeźbę.

Wystawy indywidualne:

Rysunki i pastele, galeria PWST w Krakowie, 2000 Impressionen und Tagebücher, Galeria VPÖ. Strzecha, Wiedeń 2000 Impressionen Expressionen Improvisationen, Galerie Schleifer, Wiedeń 2001 Portrety i pejzaże, Galeria Politechniki Krakowskiej Gil, Kraków 2002 Rysunek i grafika komputerowa, Centrum Sztuki Współczesnej Solvay, Kraków 2002 Rysunek i rzeźba 2005, Galeria Centrum, Nowohuckie Centrum Kultury, Kraków 2005 Pamiętnik, Galeria Lamelli, Śródmiejski Ośrodek Kultury, Kraków 2008

Udział w wystawach zbiorowych:

Bliżej w Europie, wystawa prac profesorów i studentów ASP, Saar Louis 1998 Rysunek, Galeria Wydziału Grafiki ASP, Kraków 1999

Pejzaż, Galeria Wydziału Grafiki ASP, Kraków 2000

Wystawa wyróżnionych dyplomów krakowskiej ASP, Pałac Sztuki, Kraków 2000 Wystawa zbiorowa artystów współpracujących z Galerią Licorne, Warszawa 2002 IV Triennale Polskiego Rysunku Współczesnego, Lubaczów 2002

Stypendyści Miasta Krakowa, Galeria Lamelli, Śródmiejski Ośrodek Kultury, Kraków 2004 Rysunek i malarstwo, wystawa 4 artystów, Centrum Sztuki Współczesnej Solvay,

Kraków 2004

Kraków - Warszawa, wystawa prac pedagogów krakowskiej i warszawskiej ASP, Galeria

Lamelli, Śródmiejski Ośrodek Kultury, Kraków 2005

Henkel Art Award 2005, Warszawa 2005

V Triennale Polskiego Rysunku Współczesnego, Lubaczów 2005 i Rzeszów 2006

Wystawa pedagogów Wydziału Grafiki ASP w Krakowie, BWA Nowy Sącz, 2007

Rysunek Młodych, Mazowieckie Centrum Sztuki Współczesnej „Elektrownia”

w Radomiu, 2008

VI Triennale Polskiego Rysunku Współczesnego, Lubaczów 2008 
Rysunek jest, według mnie, najbardziej podstawową formą zapisu. Dwuwymiarowa płaszczyzna kartki papieru pozwala bez ograniczeń notować myśli, emocje, upływ czasu, konstruować przestrzenie wielowymiarowe. Daje też możliwość zwięzłego, umownego zapisu złożonych treści.

Moje prace stanowią rodzaj rysunkowego dziennika. Inspiracją do ich powstania jest moja codzienność — zobaczone i zapamiętane zdarzenia, sytuacje, spotkane osoby. Szczególnie ważne są dla mnie portrety, a wizerunek twarzy jest najczęstszym motywem moich rysunków. Pojawia się na nich rodzina, bliscy, ale także niezwykłe twarze zapamiętane z tramwaju, odnalezione na starych fotografiach, nieznajomi ze zdjęć z Internetu oraz znane osoby z pierwszych stron gazet i z encyklopedii. Ludzie na portretach uchwyceni są w różnych momentach życia — od narodzin do śmierci — ujawniają różne emocje, lęki, radości. Chciałabym, aby te tak różnorodne przedstawienia złożyły się w jak najpełniejszy obraz człowieka, jego fizycznej i duchowej kondycji.

Oprócz ludzi na rysunkach pojawiają się znaki i rekwizyty. Najczęściej są kluczem do opisu przedstawionej osoby i sytuacji. Obecne na rysunkach przedmioty codziennego użytku: telefon, sztućce, buty mają szczególne znaczenie. Wierzę bowiem, że w rzeczach towarzyszących człowiekowi przez dłuższy czas odciska się niejako ślad właściciela i można z nich odczytać, choćby cząstkową, informację o życiu człowieka. W moich pracach portret człowieka składa się z wizerunku jego twarzy oraz przedstawień przedmiotów, których używał.

Przekaz prac, obok przedstawionego motywu, dopełnia ich forma. Materia rysunków, a w pracach wykonanych pastelami także kolor, podkreśla urodę życia, groteska i deformacja zaś służy ukazaniu jego „ciemnej strony”, wulgarnej, tandetnej, szpetnej. Deformacja podkreśla najbardziej charakterystyczne, indywidualne cechy modela, lecz także wydobywa uniwersalne aspekty egzystencji, z którymi każdy może się utożsamić. Groteska, zestawiona $z$ drastycznym tematem, pomaga przedstawić współistnienie tragicznego i komicznego wymiaru życia. Jego wielowarstwowość i niejednoznaczność pomaga także ukazać rozmijanie lub niedopasowanie elementów rysunku. Portrety rysowane są czarnym, mocnym konturem, wypełnianym kolorem lub czarno-białym rastrem (w pracach wykonanych piórkiem), w niektórych pracach albo niektórych ich miejscach kontur i plama rozmijają się; plama staje się autonomicznym elementem pracy, a kontur urywa się i nie określa już ściśle kształtu.

Mam nadzieję, że dzięki tym wszystkim zabiegom - paradoksalnie - moje prace stają się afirmacją życia; ukazują jego piękno. Rozumiane jako pełnia, a więc rozpatrywane nie tyle w kategoriach estetycznych (ładny nie zawsze jest tożsamy z pięknym), ile w kategoriach ontologicznych.

Rysowanie i utrwalanie w rysunkach umykających momentów życia jest też dla mnie Proustowską próbą zatrzymania czasu i uchronienia przed zapomnieniem - ludzi, wydarzeń i tego, co może „udokumentować” świat, w którym żyję. W dziele życie nie przemija, przywołanie wizerunku ocala przed śmiercią, a zanotowana chwila uzyskuje status wieczności. 

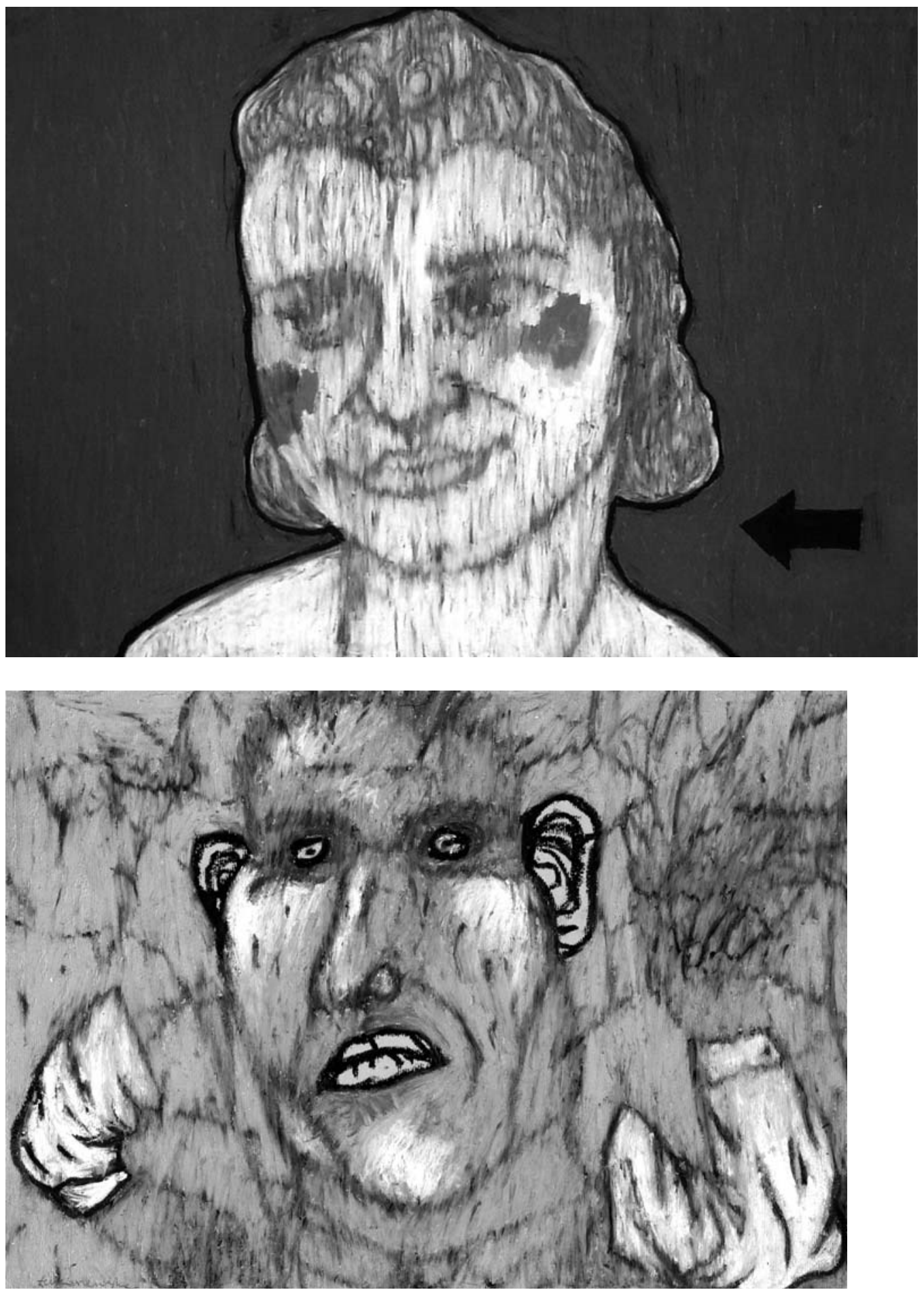

16-letnia Prakseda, pastel

na papierze, $100 \times 70 \mathrm{~cm}, 2004$
Mały, pastel na papierze;

$21 \times 29 \mathrm{~cm}, 2000$ 

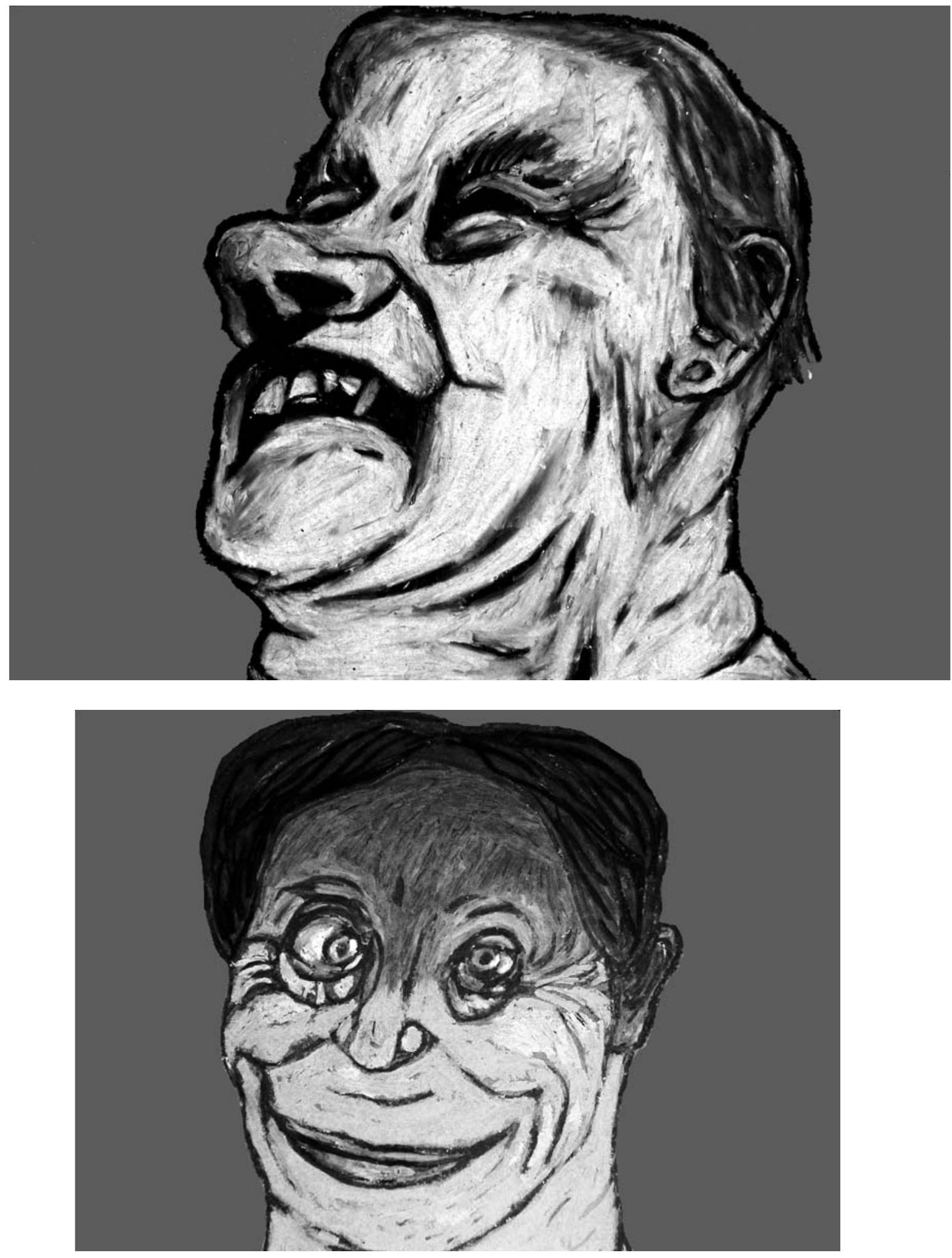


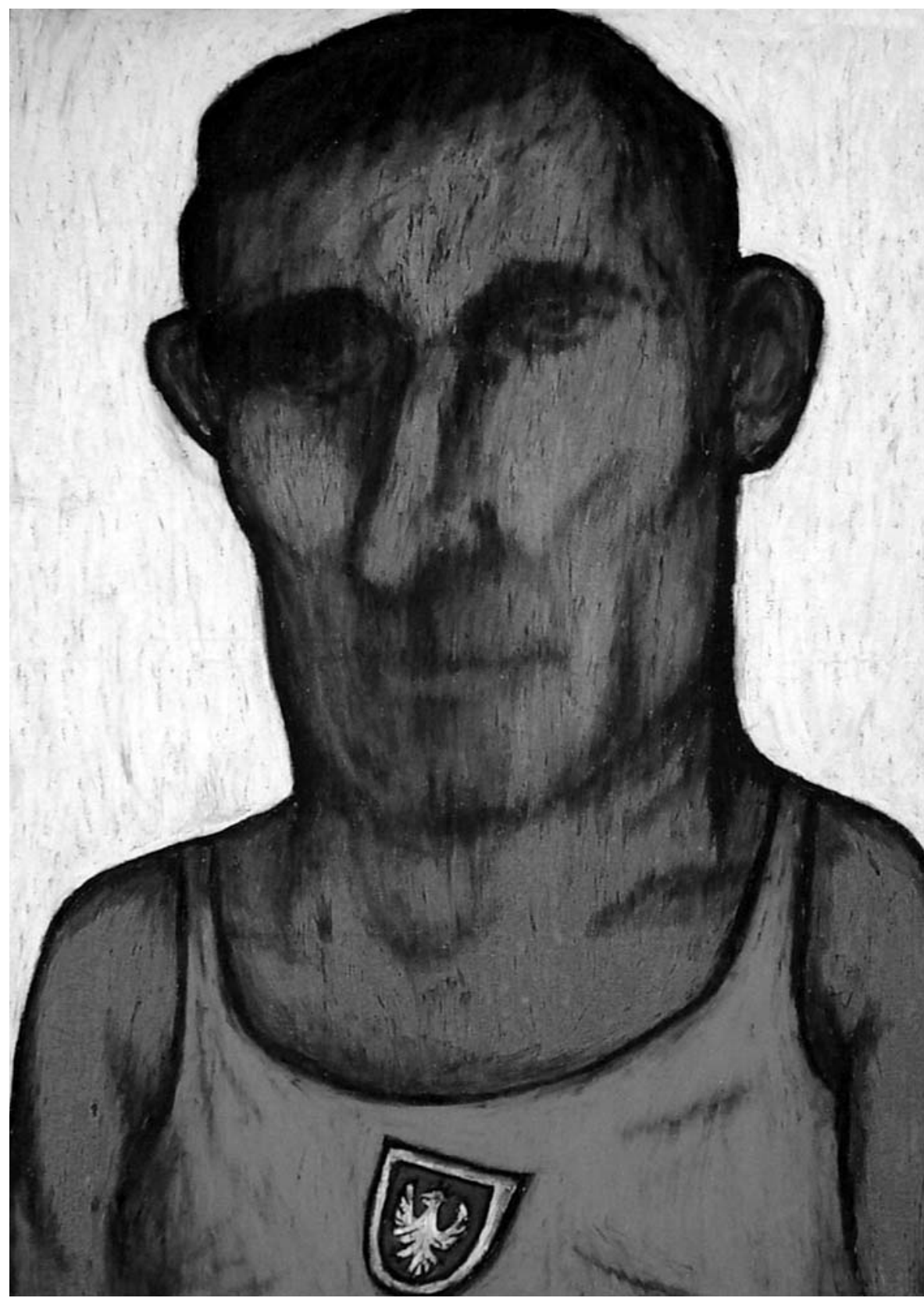

Janusz Kusociński, pastel na papierze, $50 \times 70 \mathrm{~cm}, 2005$

Ciocia Lila, pastel na papierze, $21 \times 29 \mathrm{~cm}, 2009$
Maryjka, pastel na papierze,

$21 \times 29 \mathrm{~cm}, 2009$ 


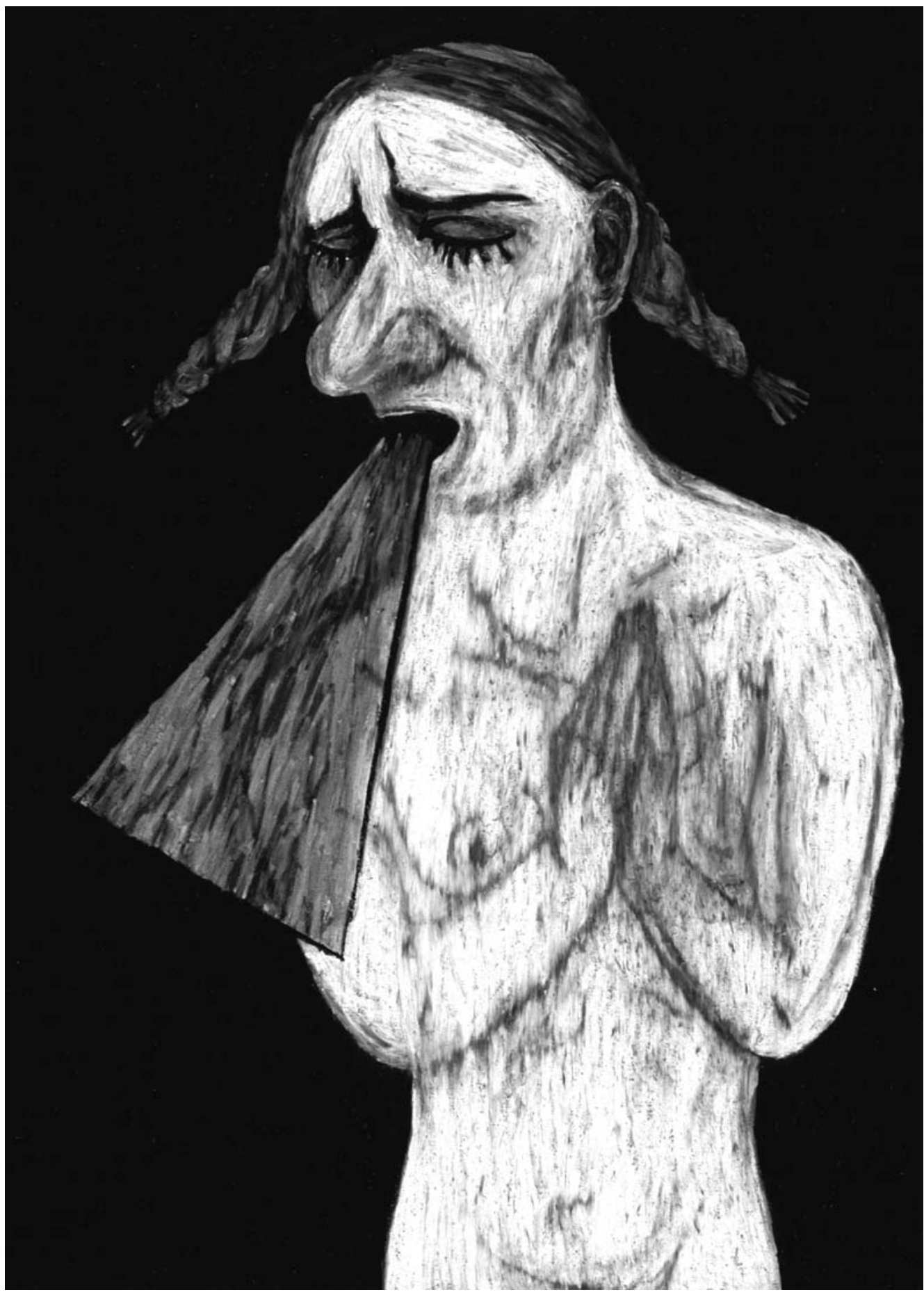

Vomit metafizyczny, pastel na papierze, 

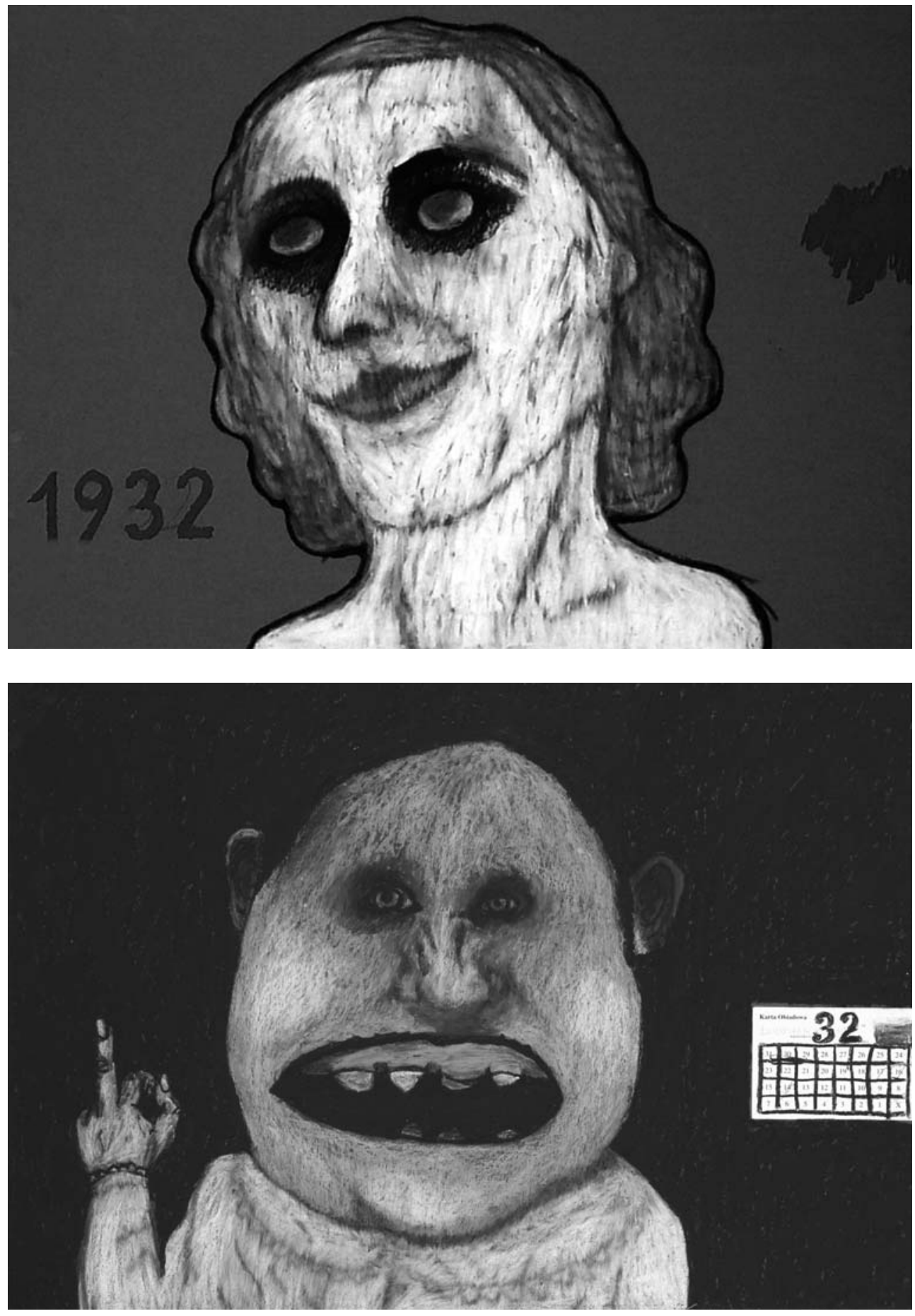

Miss 1932, pastel na papierze, $50 \times 70 \mathrm{~cm}, 2004$
Rekin, pastel na papierze,

$50 \times 70 \mathrm{~cm}, 2007$ 


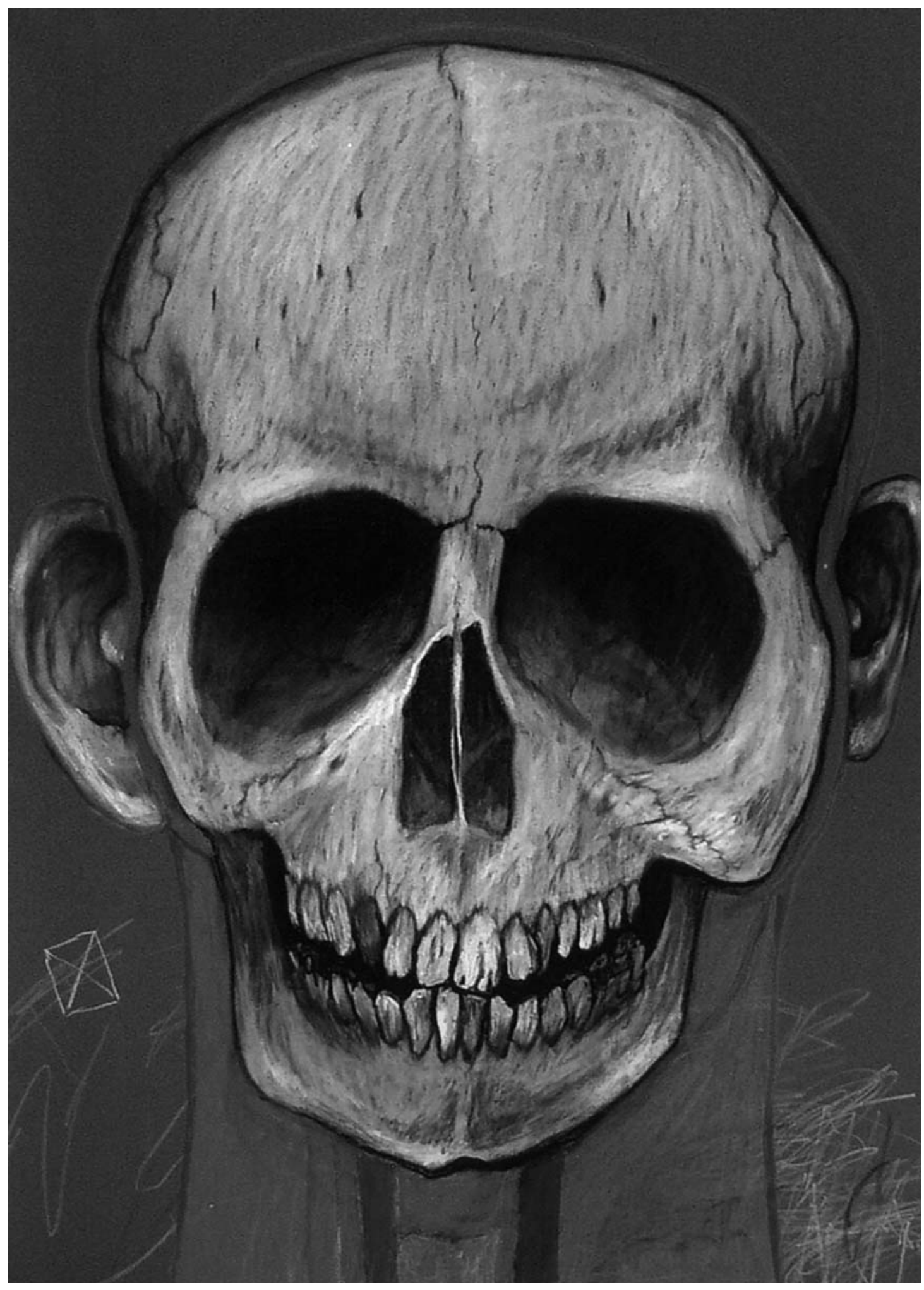




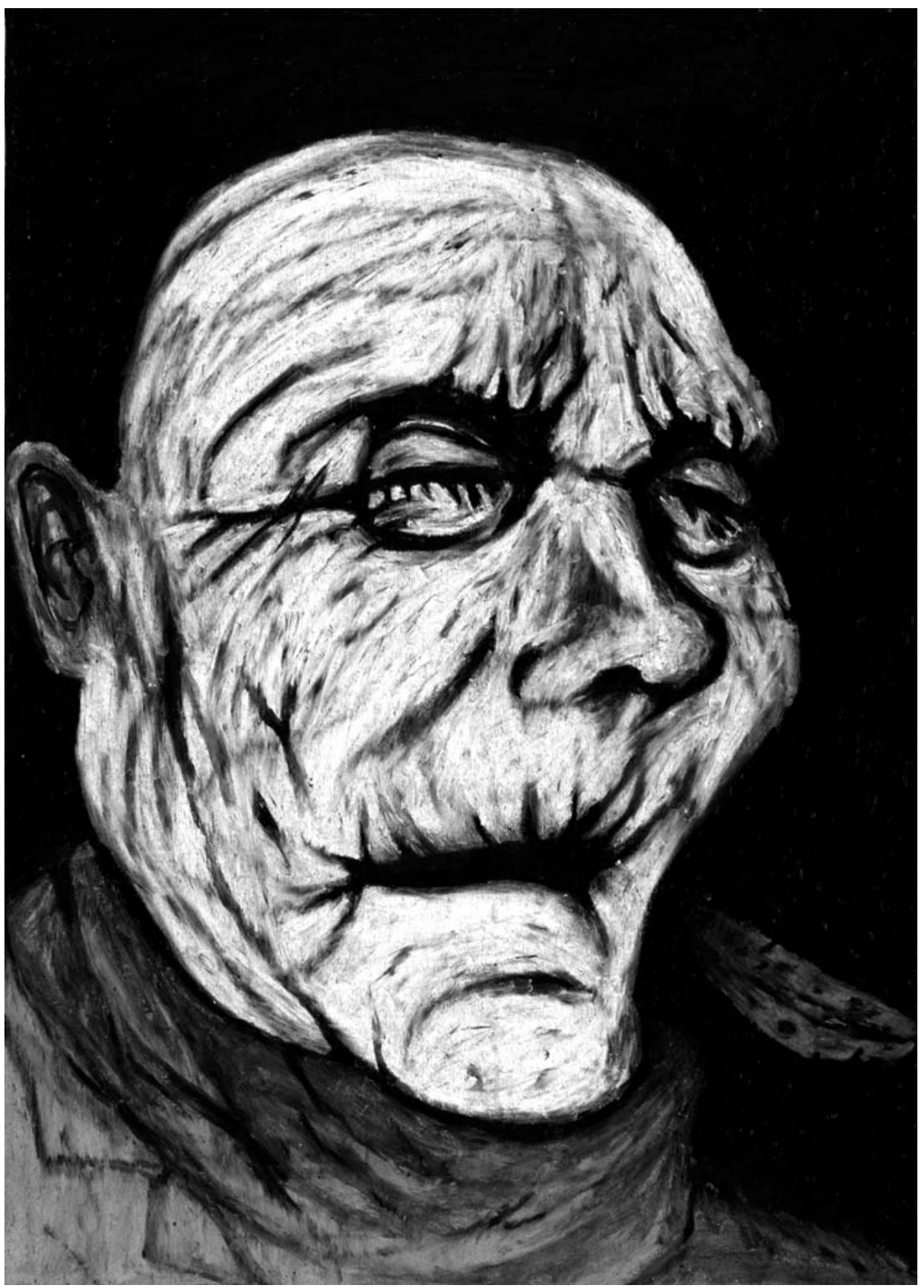

Czaszka, pastel na papierze, $100 \times 70 \mathrm{~cm}, 2008$
Dziadek,

pastel na papierze, $25 \times 35 \mathrm{~cm}, 2003$ 

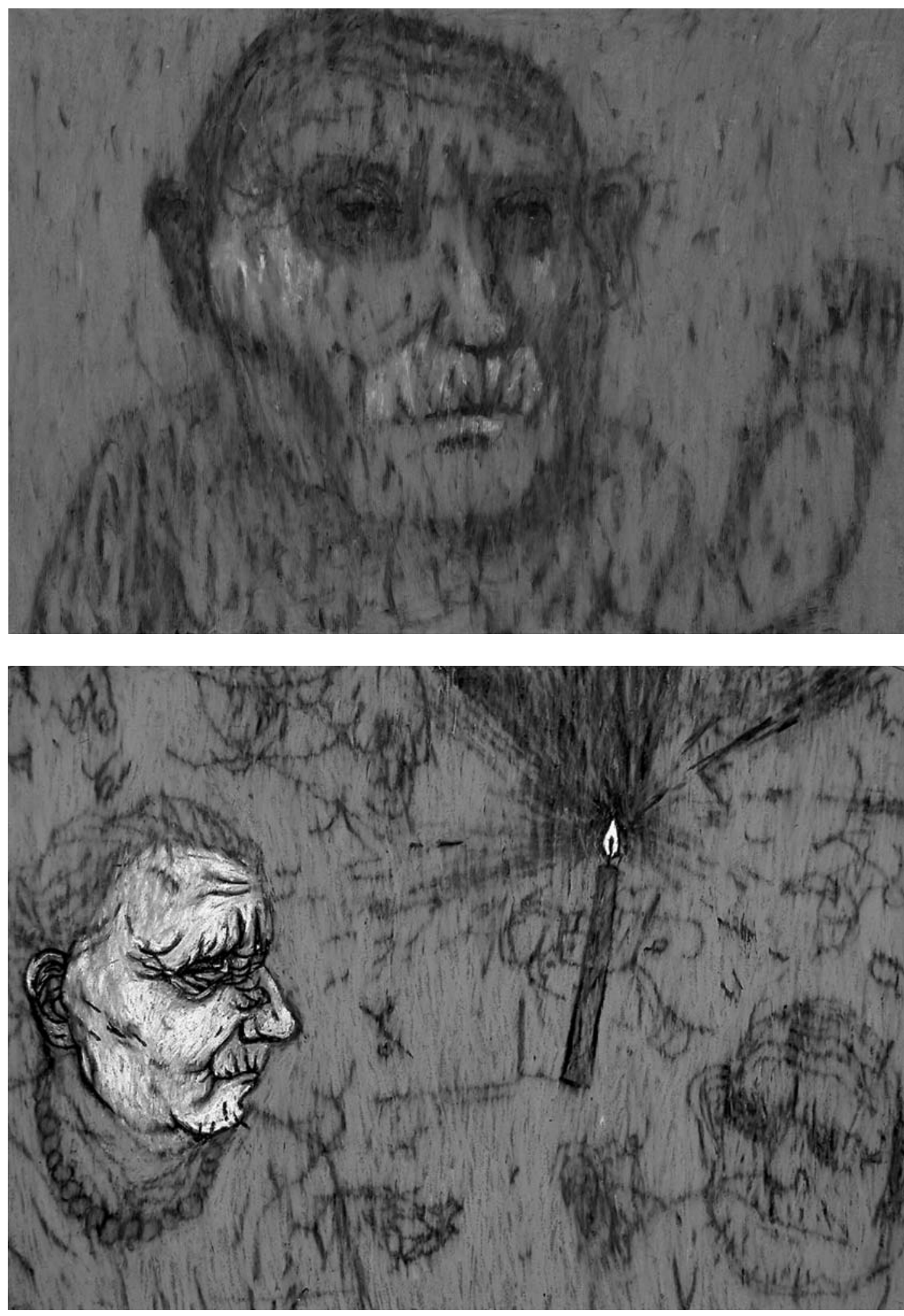


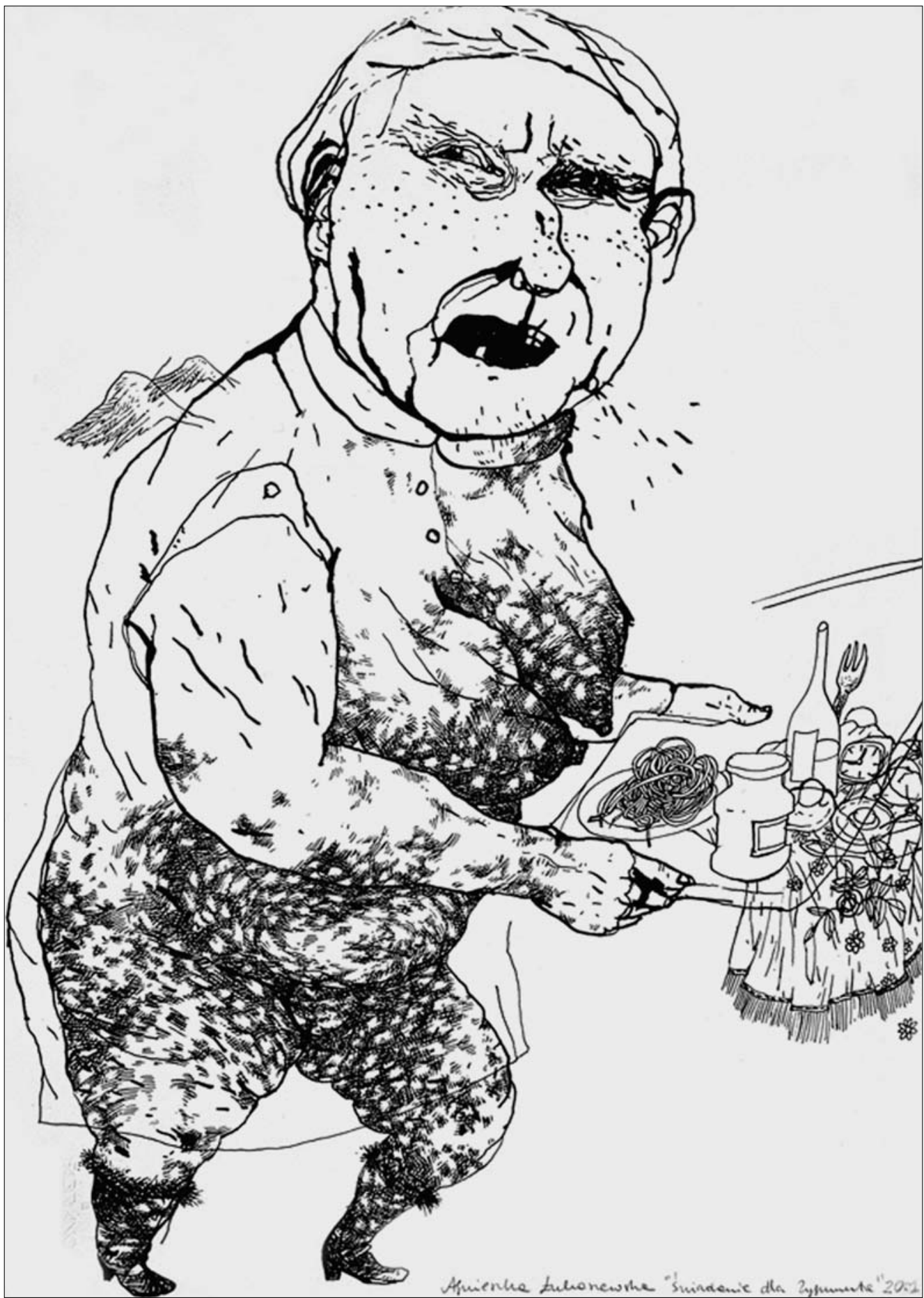

Śniadanie dla Zygmunta,

tusz, piórko, $25 \times 35$ cm, 2001
Portret, tusz, piórko,

$25 \times 35 \mathrm{~cm}, 2001$ 


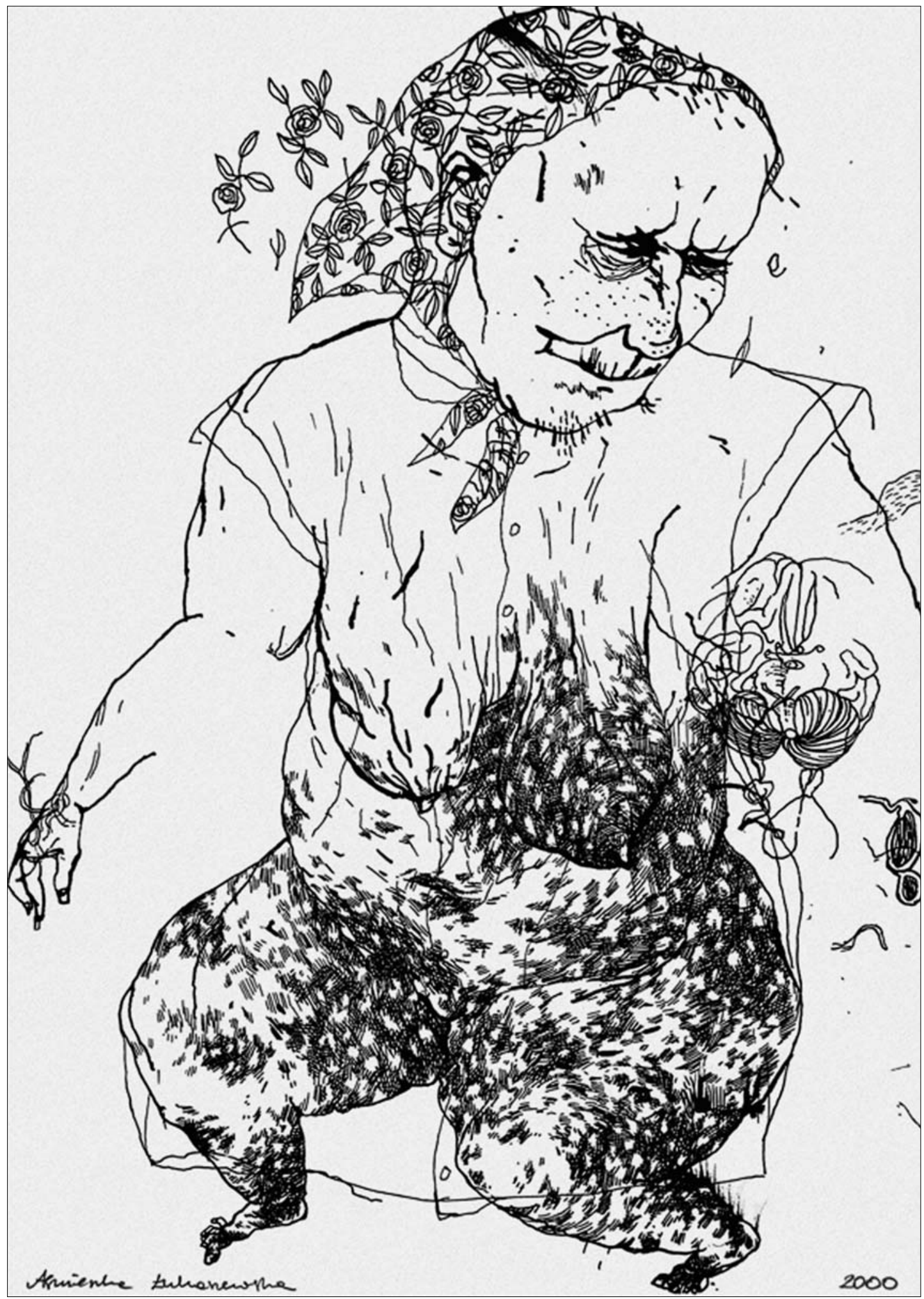



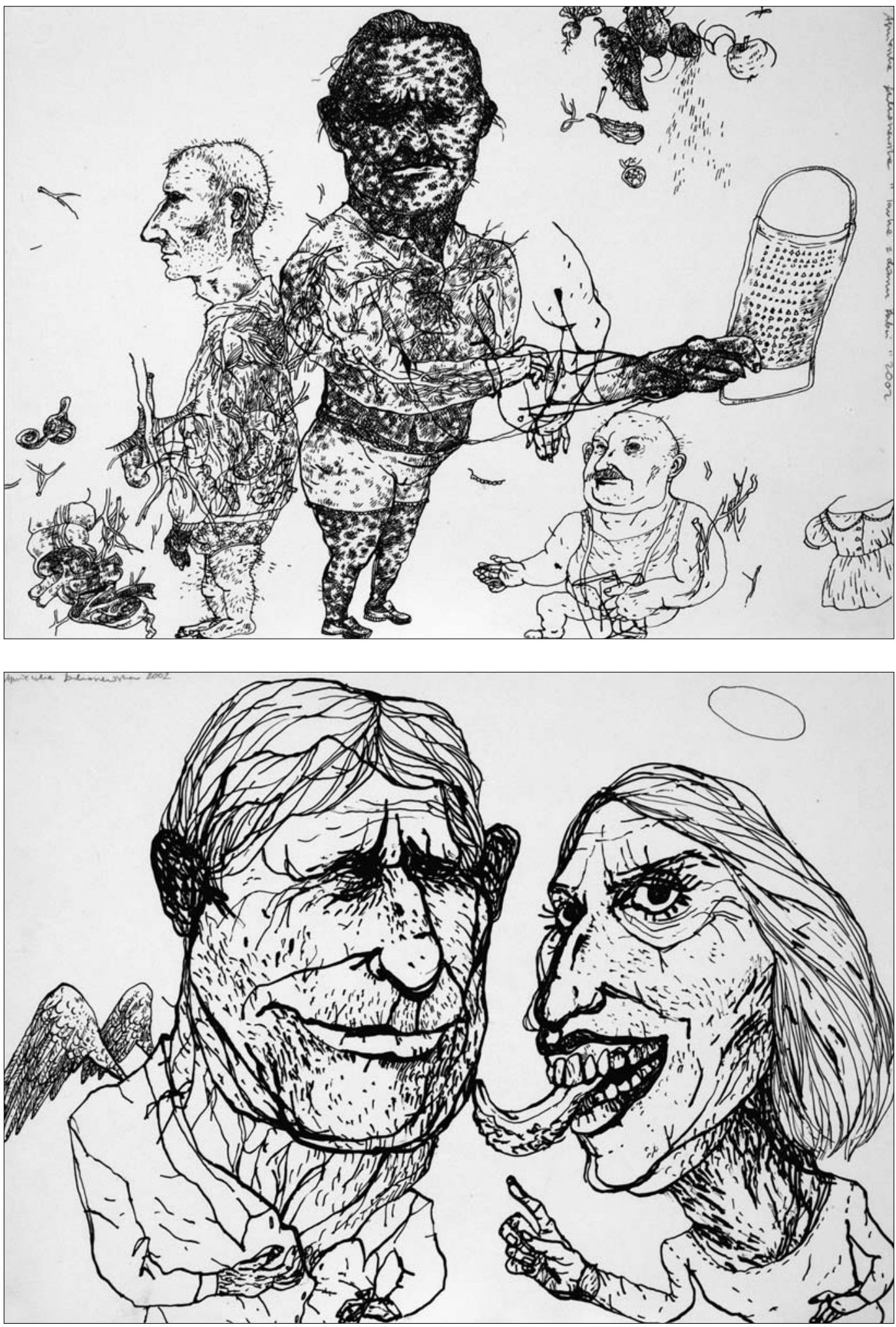


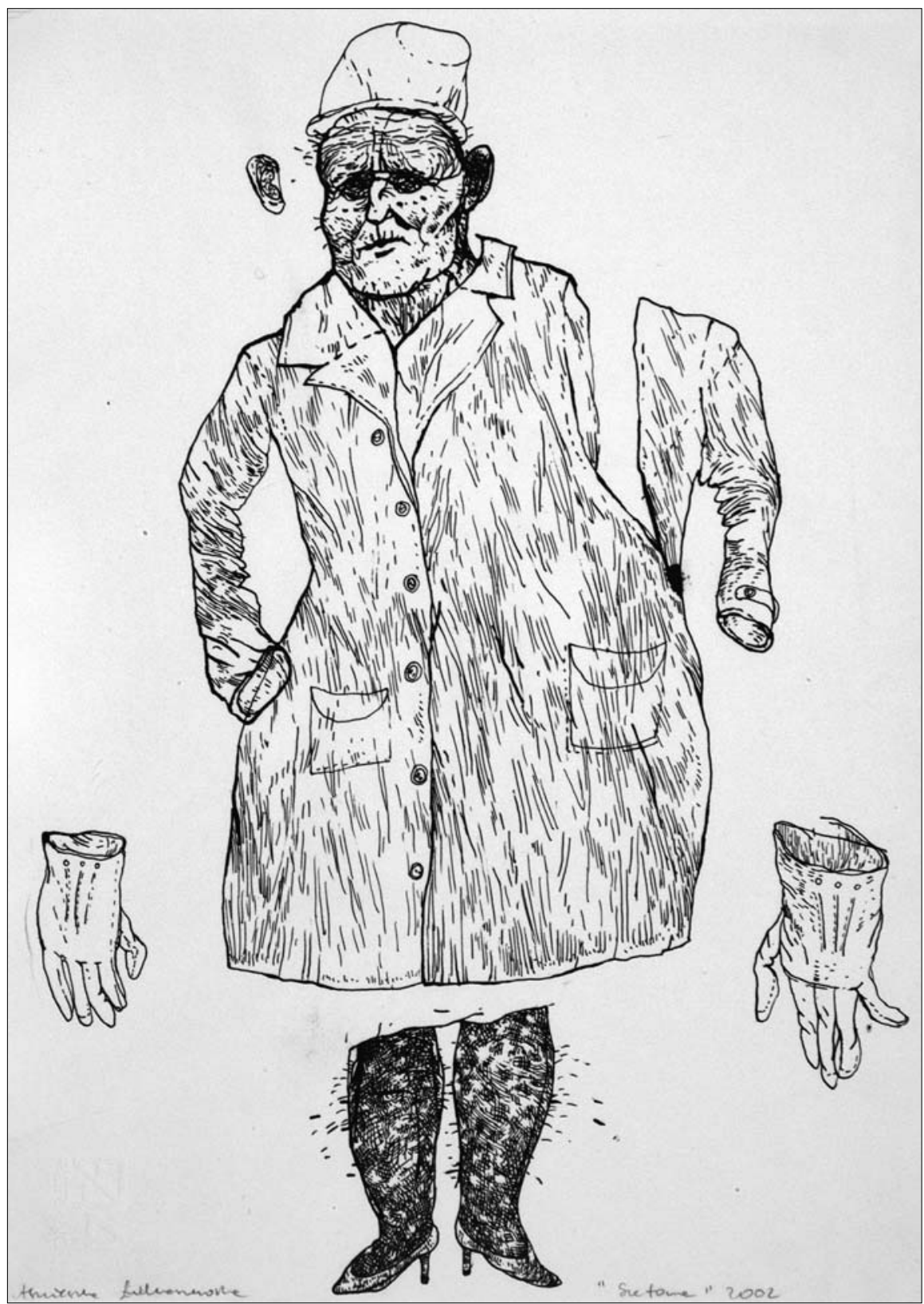

Szefowa, tusz, piórko, $25 \times 35 \mathrm{~cm}, 2002$

Tarka, tusz, piórko, $25 \times 35 \mathrm{~cm}, 2001$
Rozmowa, tusz, piórko,

$25 \times 35 \mathrm{~cm}, 2003$ 

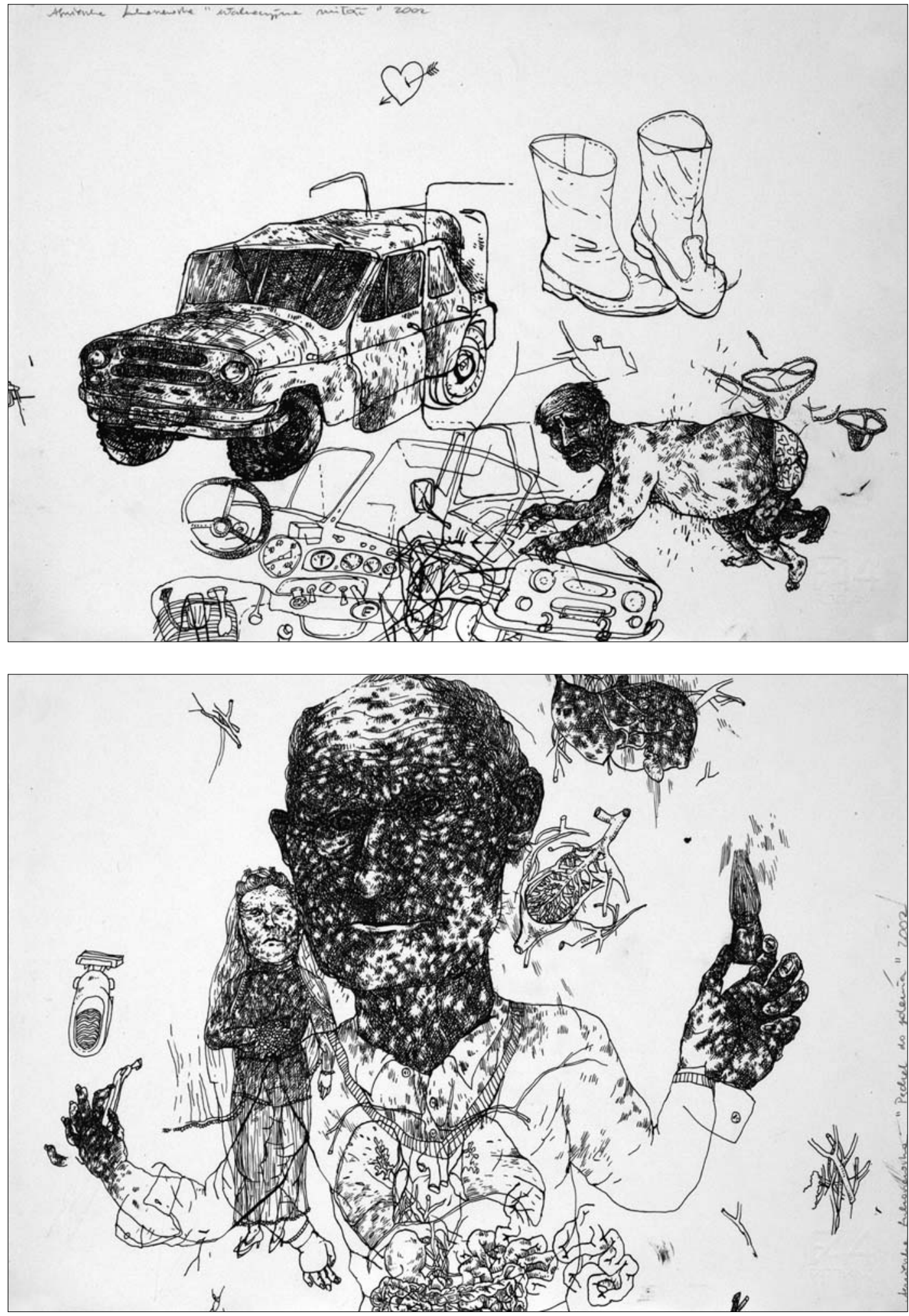


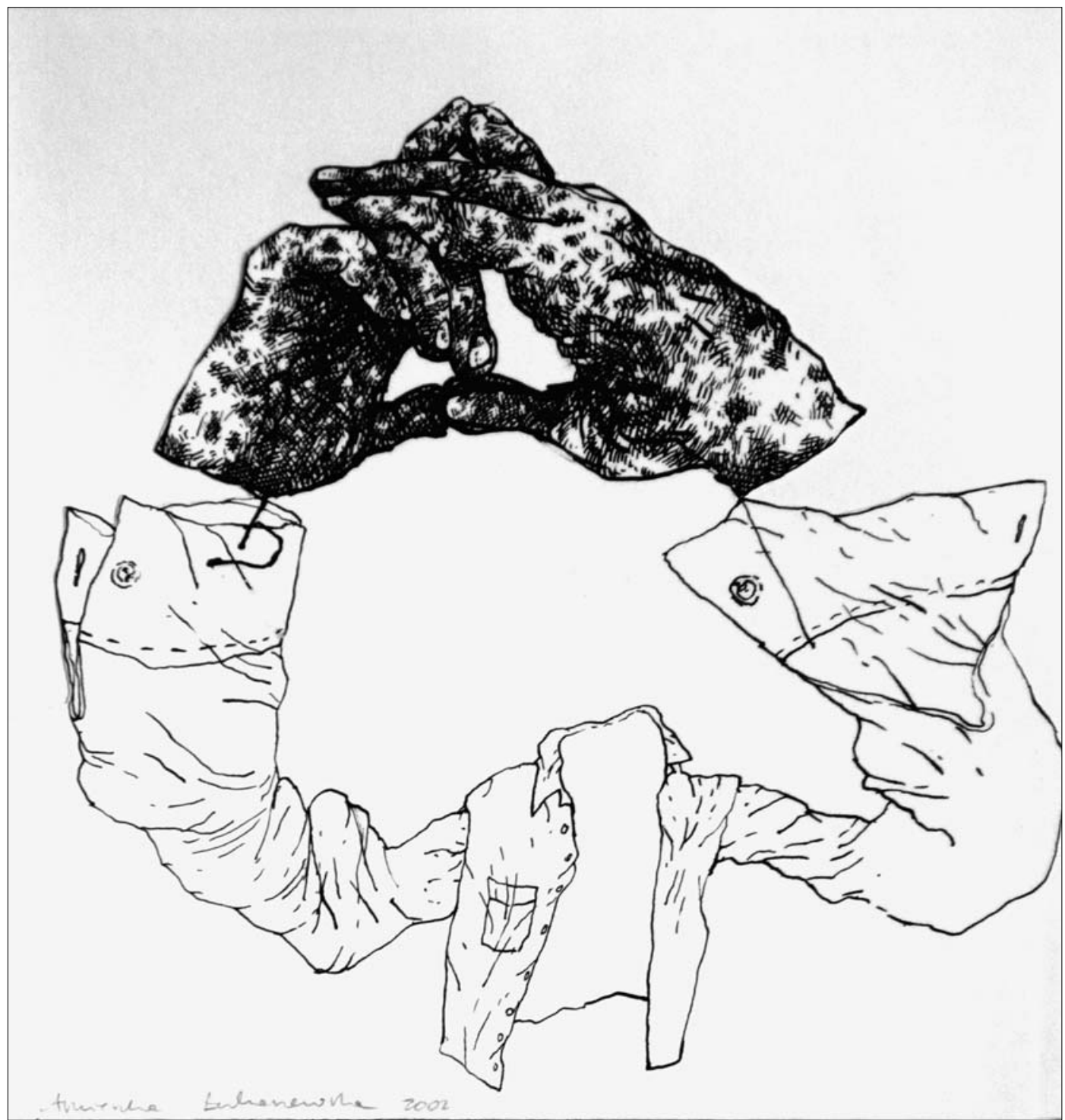

Portret, piórko, tusz,

$25 \times 26 \mathrm{~cm}, 2002$

Wakacyjna miłość,

tusz, piórko, $25 \times 35 \mathrm{~cm}, 2002$
Pędzel do golenia,

piórko, tusz, $25 \times 35 \mathrm{~cm}, 2002$ 


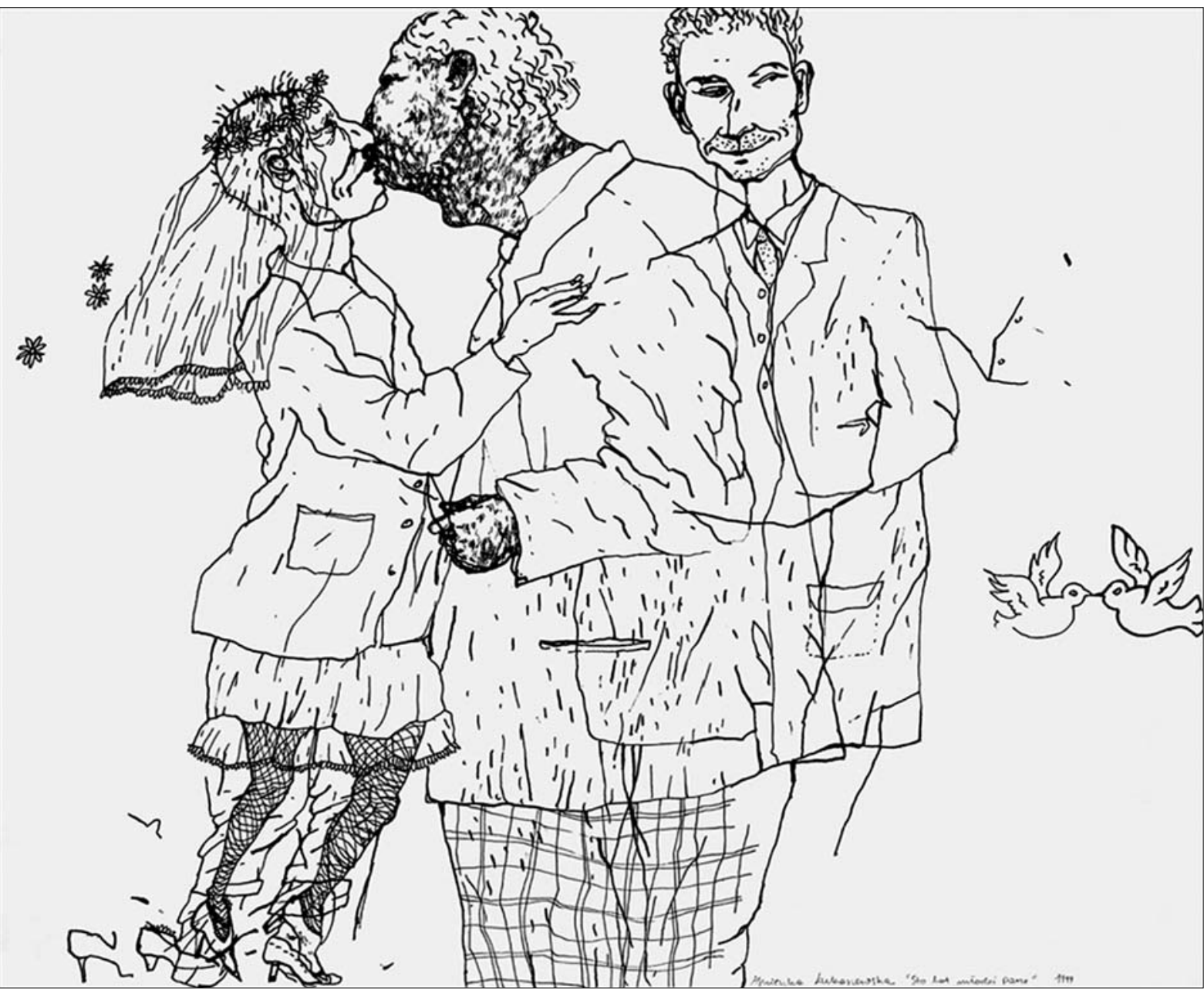

Sto lat młodej parze, piórko, tusz, $25 \times 30 \mathrm{~cm}, 1999$

Pińczów, piórko, tusz, $18 \times 25 \mathrm{~cm}, 1998$
Pińczów, piórko, tusz,

$18 \times 25 \mathrm{~cm}, 1998$ 

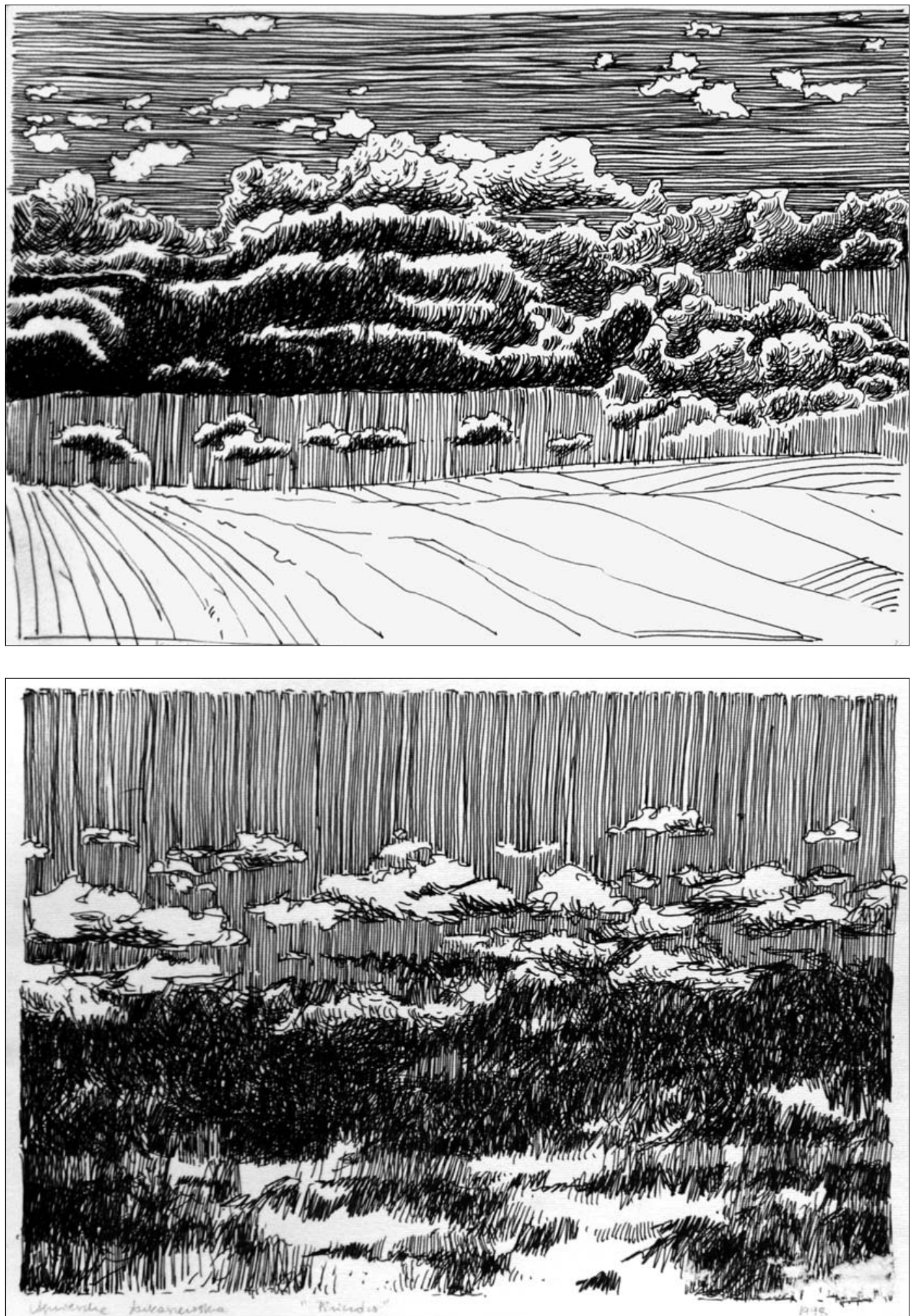


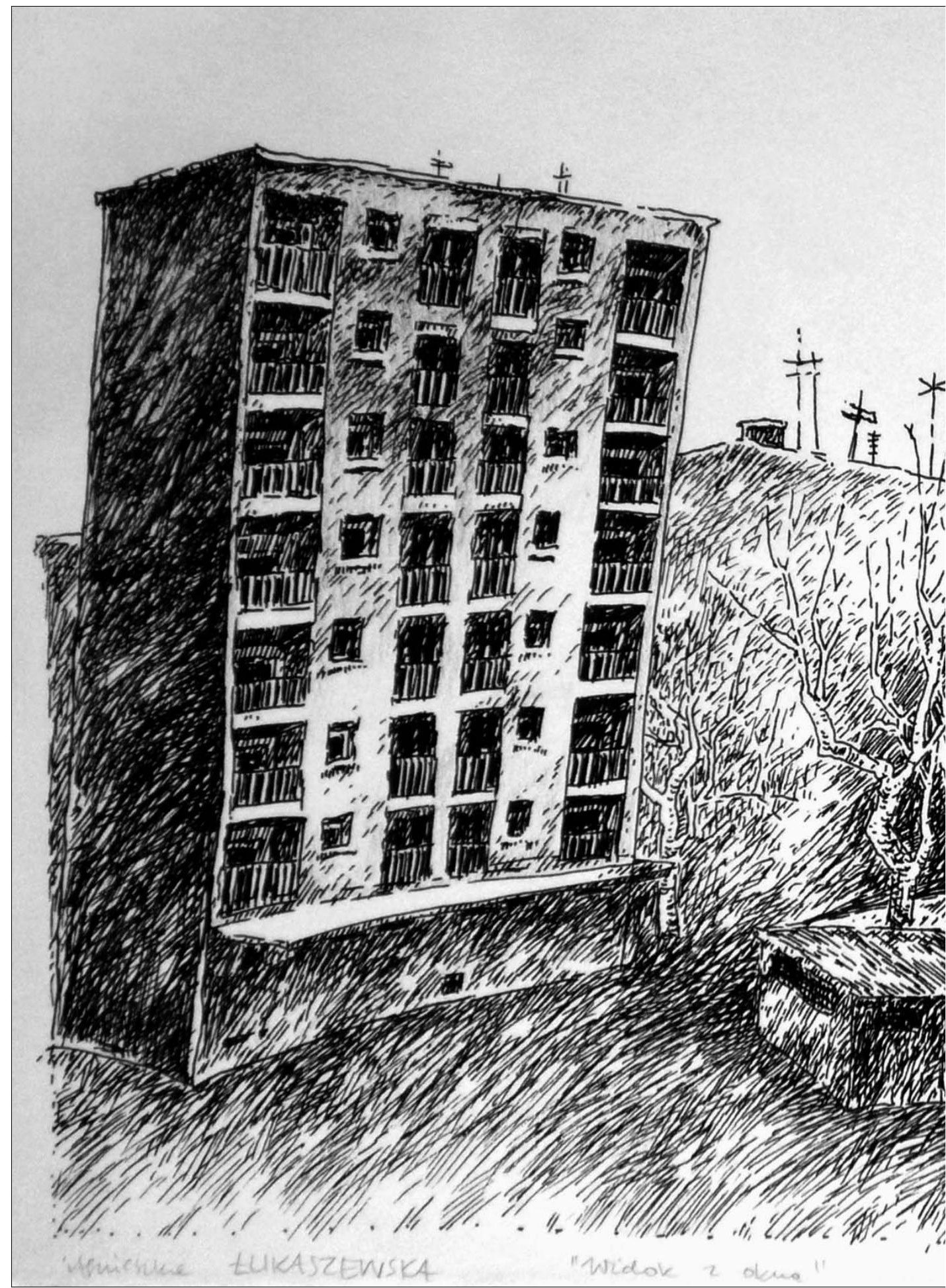




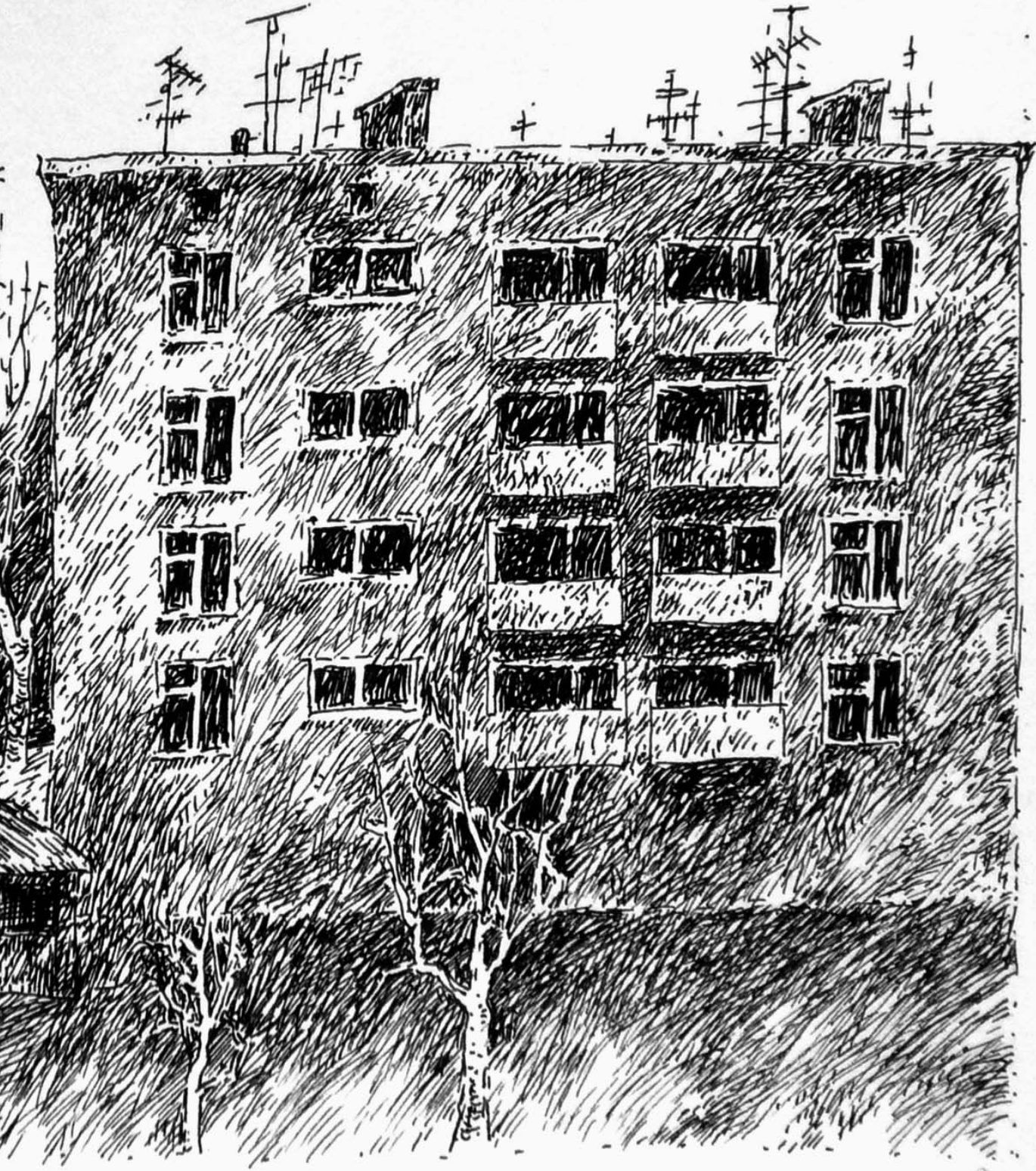



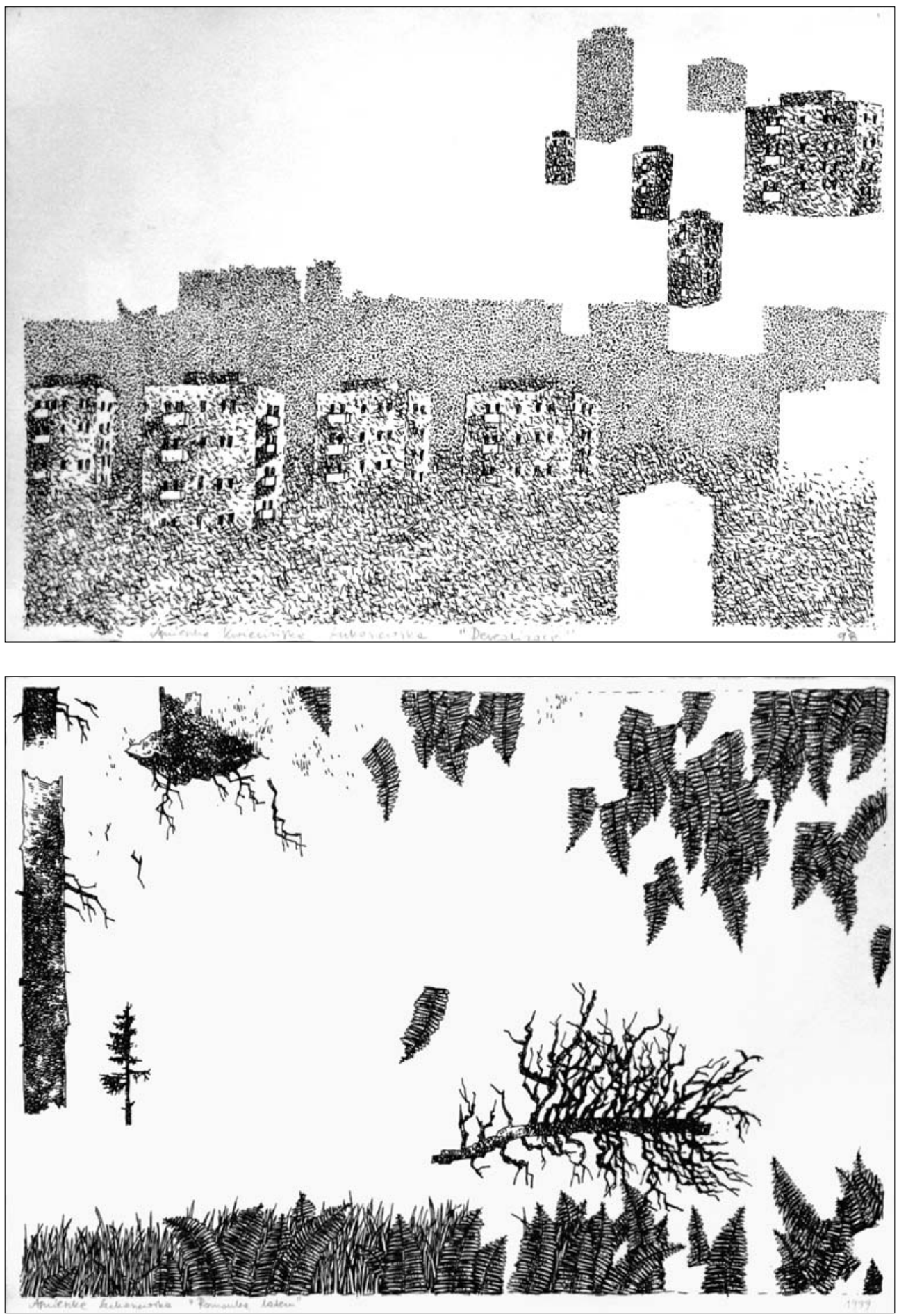

Derealizacja, piórko, tusz, $25 \times 35 \mathrm{~cm}, 1998$
Romanka latem, piórko, tusz, 25 X $35 \mathrm{~cm}, 1995$ 